Artocarpus nobilis and Terminallia catappa. Artocarpus nobilis plants were rejuvenated; young shoots were seen in mature stems of the plant. Some herbs were found in coastal belt, Nagadarana, Tridax procumbanse, Attana (Datura spps) and Maturutala. Antigonan spps and Muhudu bimthambaru (Ipomoea pescapre) were seen as creeping type plants. Crowfoot grass and Bala thana grass were also recorded near the coast. Although practically no damage was recorded for Katu andara, in some certain areas of Hambantota District, it has started to germinate, where it was not present may be due to high tolerance to salinity.

Tree species of Pandanus, Cocos nucifera, Terminalia catappa, Manilkara hexandra . Berringtonia asiatica, Prospis juliflora, Azadirachta indica, Hibiscus tiliaceus, Sooriya, Tamarindus indica, Salvadora persica and Feronia limonia and shrubs species of Maduruthala, Tridax, 'Nagdarana, Attana and Wara (Calotropis gigantean), and creeping type plants species of Balathana grass, Crowfoot grass, Neranchi, Ipomoea pescapre can be recommended for rehabilitation of maritime vegetation of affected areas in Hambantota District.

\title{
$\underline{090}$
}

\section{The effects of tsunami on small and medium enterprises (SME's): Case in Hambantota district}

\section{$\mathrm{K}$ Silva and S Amaratunge}

South Asia and a part of Africa was struck by a Tsunami, a long high sea wave caused by underwater earthquake, on the 26 December 2004 . In Sri Lanka costal areas around country were badly affected and entire social, economic system in those areas were disintegrated and had to depend on outside support. Those areas were less developed and income sources were intertwined with sea. In the absence of large industries economic activities were focused on Small and Medium scale businesses (SMEs) in most of these areas. This research made an effort to identify the rebuilding achievements of SME's in post Tsunami period in both social and economic contexts.

Hambanthota was selected for the study and 25 SMEs ${ }^{1}$ were selected randomly in Rathupasgodalle town and Mirijjavila. Cluster of SME's randomly selected included traders, manufactures, fishing, representing services. It was a quantitative study and empirical statistics were studied to identify and interpret objective of the study. Structured questionnaire was used and comprised before and after Tsunami positions. In all most all cases partner or proprietor was interviewed, researches made interpretative approach in analyzing the responses and arriving conclusions.

The study has found that SME's had started in small way but do not have a strength to recommence on their own to the capacity they were hence look for financial assistance. Lack of accepted collateral had been a major issue as the banks financial services maintained averse approach and only $8 \%$ had received financial assistance. Self-employment and SME's had offered income source second to Government employment. Non-operations of SME's created a vacuum for employment opportunities/ income sources. $99 \%$ of employed were from surrounding areas thus made economic instability to families. Authorities had considered SME's as mere business entities and ignored the fact they play in social and economic aspect. SME's nor the society was ever prepared for a disaster in a such magnitude. They did not have any plan for risk evasion or business continuity. Only marginal number had insurance although one third had liability for loans/leases. 